\title{
SYNTHESIS, CHARACTERIZATION AND BIOLOGICAL PROPERTIES OF NEW CODEINE FE(III) COMPLEX
}

\author{
SHAHRIAR GHAMAMI, MOJDEH GOLZANI*, AMIR LASHGARI
}

Department of Chemistry, Faculty of Science, Imam Khomeini International University, Qazvin 34148-96818, Iran

\begin{abstract}
The reaction of $\mathrm{FeCl}_{3}$ hexahydrate with $\mathrm{C}_{18} \mathrm{H}_{20} \mathrm{NO}_{3} \cdot \mathrm{PO}_{4}$ in acetonitrile produced new complex with general formula $[\mathrm{Fe}(\mathrm{L})] \mathrm{Cl}$, $(\mathrm{L}=$ codeine). Characterization of the ligand and its complex were made by elemental analysis, FT-IR, ${ }^{1} \mathrm{H}-\mathrm{NMR}$, Raman and UV-visible spectroscopy. This new complex showed antitumor activity against two kinds of cancer cell lines: AGS (Stomach) and MCF-7 (Breast). Cell cytotoxic effects of the ligand and its complex were assayed by MTT and Natural-red tests. The antibacterial activity of ligand and complex against Pseudomonas aeruginosa, Staphylococcus aureus, Streptococcus pyogenes and Escherichia coli were also examined.
\end{abstract}

Keywords: Codeine; Fe(III) complex; Synthesis; Anti-tumor; AGS and MCF-7; Antibacterial.

\section{INTRODUCTION}

Natural products play an important role in diseases control and treatment. The plants extracts are used in the treatment of human diseases all the time. From the last century, a scientific interest for phototherapy increased in several medical fields such as immunology, hematology and oncology [1-5].

Currently there are three major ways of treating cancer: radiation therapy, surgery and cytotoxic drugs. Application of plants in medicine has affected the identification of natural compounds such as cocaine, morphine, vinblastine, tax land codeine [5-8].

Many different coordination compounds and the mechanism of cytotoxic action have been discussed with regard to the development of new antitumor agents [8-15]. Numerous medicinal plants have been screened extensively for their antimicrobial potential worldwide $[1,11]$. Morphine and its derivatives have received considerable attention as narcotic and used in lenitive drudge products. Morphine plays an important role in the therapy of acute and chronic pain. Exogenously delivered morphine acts in the body by activating different subtypes of opioid receptors [14].

Over the last decades, proposals have accumulated that morphine present in mammalian tissues and fluids comes not only from an exogenous or dietary origin, but may also be biosynthesized de novo. Latest studies have unequivocally proven the existence of a mammalian morphine biosynthetic pathway [15], which consists of at least 19 steps and is different in its primary steps from that occurring in plants [16]. Meanwhile the endogenous morphine biosynthesis takes place in mammals, their cells and tissues are constantly exposed to certain amounts of morphine and its precursors [17].

Investigation of lithium effect in opioid receptors on inhibitory avoidance response in mice has been reported. The results suggest that the opioid receptors in the central nervous system may be involved in the retrieval of lithium state dependent learning [18]. The lithium efficacy in controlling behaviors related with dopamine stimulants and manic states has been proposed [19]. Thus, it may be suggested that lithium's action may be mediated through dopamine receptors $[20]$.

Furthermore interactions between lithium and opioids have been reported. There is evidence that lithium is able to affect some actions of morphine. In particular, it has been shown that lithium inhibits morphine withdrawal signs in morphine-dependent mice [21], reduces the self-stimulation facilitated by morphine and the expression of tolerance to morphine [22] and alters the morphine induced analgesia in mice [23]. Both drugs produce a conditioned taste avoidance response and suppress schedule-induced polydipsia [24]. Another morphine precursor codeine, which stands in the biosynthetic pathway after salutaridinol, had a higher partial agonist efficacy. Their metal chelates are of interest due to their fascinating chemistry as well as antimicrobial and anti-cancer activities. The other natural ligand from plants such as phenolic compound of mono and sesquiterpenoid, flavonoids also can be used in synthesis of metal complex [25].

Codeine is generally named codeine phosphate (Cod.P), morphine3-methyl ether phosphate, methyl-morphine phosphate, or morphine monomethyl ether phosphate. It takes the general formulae of $\mathrm{C}_{18} \mathrm{H}_{24} \mathrm{NO}_{7} \mathrm{P}$. It also takes the structure formula as given by Gull and et al in Figure 1. Recently, the complexion ability of codeine towards transition metals is investigated by Zayed et al. [27] and [28] using combined physic-chemical methods of analyses. They concluded the high stability of the formed complexes which are of the essential biological roles.

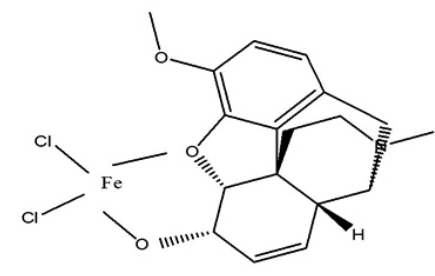

Cod Fe(III) complex

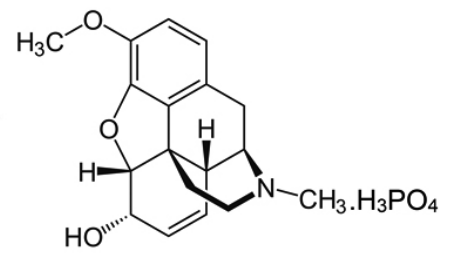

Codeinephosphate
Figure 1.The structural formula of codeine phosphate anhydrate and its complex of Fe (III).

The main thrust of this study is to synthesize codeine phosphate transition metal complex bearing the natural ligand (codeine) and characterization of it and its $\mathrm{Fe}(\mathrm{III})$ complex by ${ }^{1} \mathrm{H}-\mathrm{NMR}$, FT-IR, UV-Visible, Raman and elemental analysis, as well as the study of its antitumor and antibacterial activity .

\section{MATERIALS AND METHODS}

Melting points were determined using Electro thermal Melting Point equipment. The FT-IR spectra were recorded in the solid state ( $\mathrm{KBr}$ pellets) in the range $400-4000 \mathrm{~cm}^{-1}$ using a Bruker FT-IR Pensor-27 spectrometer. The UV-Vis spectra were recorded in acetonitrile solution, in the range 200$800 \mathrm{~nm}$, using a Perkin Elmer-Lambda 25 spectrometer. The ${ }^{1} \mathrm{H}-\mathrm{NMR}$ were recorded at 298K, on Bruker $500 \mathrm{Mz}$ Spectrometer, in DMSO-d ${ }_{6}$. Elemental analysis was recorded by Herius instruction. The chemical shifts are referred to DMSO signal at $3.38 \mathrm{ppm}$. The Raman spectra of, Physics Department, Tarbiat Modares University by using a Thermo Nicolet Almega dispersive microRaman scattering spectrometer operating by a $532 \mathrm{~nm}$ laser line as the second harmonic of a Nd: YLF laser.

The $\mathrm{FeCl}_{3}$ salt, acetonitrile and codeine was purchased from Merck. The microorganisms tested were Pseudomonas aeruginosa, Staphylococcus aureus, Streptococcus pyogenes and Escherichia coli from clinical isolates. The Agar Nutrient was purchased from Aldrich. The human Stomach (AGS) cell line and the human Breast (MCF-7) cell lines, used for treatment with the drugs from Pasteur institute in Tehran, Iran.

\section{Synthesis of the metal complex: General Method}

A solution of metal salt dissolved in acetonitrile added a dually to a stirred acetonitrile solution of the ligand (codeine), in the molar ratio 1:1 (metal : ligand). The reaction mixture was further stirred for $4-5 \mathrm{~h}$ to ensure of the completing and precipitation of the formed complexes. Finally, the complexes dried in vacuum desiccators over anhydrous $\mathrm{CaCl}_{2}$.

\section{Antibacterial activity}

The microorganisms tested were Pseudomonas aeruginosa, Staphylococcus aureus, Streptococcus pyogenes and Escherichia coli from clinical isolates. The agar nutrient was purchased from Aldrich. Antibacterial activity of the complex and ligand was investigated against 4 bacterial strains by the paper disk diffusion technique [4]. An inoculums of 0.5 McFarland standard $\left(1.5^{*} 10^{8} \mathrm{cfu} / \mathrm{ml}\right)$ was applied on Mueller Hinton agar (a depth of $4 \mathrm{~mm}$ 
in a petridish of $100 \mathrm{~mm}$ diameter). Maximum 6 discs were applied on each plate and they were incubated at $37^{\circ} \mathrm{C}$ for 24 hours. Zone of inhibition was measured including the disc diameter $(6 \mathrm{~mm})$ in Table 1 .

Table 1. Zone of growth inhibition of the test compounds against the bacteria.

\begin{tabular}{|c|c|c|c|c|}
\hline Samples & $\begin{array}{c}\text { Pseudomonas } \\
\text { aeruginosa }\end{array}$ & Staphylococcus aureus & Streptococcus pyogenes & $\begin{array}{c}\text { Escherichia } \\
\text { coli }\end{array}$ \\
\hline $\mathrm{C}_{18} \mathrm{H}_{20} \mathrm{NO}_{3} \cdot \mathrm{PO}_{4}$ & - & - & - & $10 \mathrm{~mm}$ \\
\hline$\left[\mathrm{Fe}\left(\mathrm{C}_{18} \mathrm{H}_{19} \mathrm{NO}_{3}\right)\right] \mathrm{Cl}_{2}$ & - & - & - & - \\
\hline
\end{tabular}

\section{Anticancer activity}

( $5 \alpha, 6 \alpha)-7,8$ - did hydro - 4,5 epoxy - 3 methoxy - 17 - methyl morphinan - 6 - phosphate (DEMP), $\left[\mathrm{Fe}\left(\mathrm{C}_{18} \mathrm{H}_{19} \mathrm{NO}_{3}\right)\right] \mathrm{Cl}_{2}$, were assayed for cytotoxicity against AGS and MCF-7 cell lines. The two cell lines were provided by the Pasteur Institute of Iran. AGS and MCF-7 cells were grown at $37^{\circ} \mathrm{C}$ in a humidified atmosphere with $5 \% \mathrm{CO}_{2}$, with RPMI- 1640 supplemented with $10 \%$ fetal bovine serum (FBS). The procedure for cytotoxicity studies was similar to that reported earlier [9]. After incubation periods of 72 hours for all cell lines, the cell concentrations were determined both in control and in drug-treated cultures. Cytotoxicity of total acetonitrile extract of codeine and its complex were examined on cell lines. The percentage of cell viability was determined by MTT assay. All experiments were done in six times.

\section{RESULTS AND DISCUSIONS}

Structure investigation of codeine ligand by FT-IR, ${ }^{1} \mathrm{H}-\mathrm{NMR}$ and $\mathrm{UV}$ Visible

It is of great interest to study the chemistry and reactivity of codeine drug because of its importance in medicine similar to morphine. At first, codeine characterized by FT-IR, ${ }^{1} \mathrm{H}-\mathrm{NMR}$ and UV-Visible methods. The FT-IR spectrum of codeine as $\mathrm{KBr}$-disc was recorded and assigned as bands in Table 2 .

Table 2. The FT-IR characteristics of codeine drug.

\begin{tabular}{|c|c|}
\hline $\mathbf{v}\left(\mathbf{c m}^{-1}\right)$ & Assignment \\
\hline $3510-3773$ & $-\mathrm{OH}$ \\
\hline 2500 & $-\mathrm{NH}$ \\
\hline $1071-1125$ & $\mathrm{C}-\mathrm{O}-\mathrm{C}$ \\
\hline 1269 & $\mathrm{C}-\mathrm{N}$ \\
\hline 1642 & (Alkense) $\mathrm{C}=\mathrm{C}$ \\
\hline 1515 & (Aromatic) $\mathrm{C}=\mathrm{C}$ \\
\hline 1260 & (CO) $(\mathrm{O}-\mathrm{Me})$ \\
\hline $871-788$ & Two adjacent $\mathrm{H}$ aromatic \\
\hline
\end{tabular}

The ${ }^{1} \mathrm{H}-\mathrm{NMR}$ of codeine in deuterium oxide was recorded using tetramethyl silane (TMS) as a reference standard and was assigned as given in Table 3, 4 .

Table 3. ${ }^{1} \mathrm{H}-\mathrm{NMR}$ identification of codeine.

\begin{tabular}{|c|c|}
\hline Chemical shift $(\boldsymbol{\delta})$ & Assignment \\
\hline $6.78(\delta)$ & $1 \mathrm{H}$ \\
\hline $6.95(\mathrm{~d})$ & $2 \mathrm{H}$ \\
\hline $5.78(\mathrm{~d})$ & $7 \mathrm{H}$ \\
\hline $5.40(\mathrm{~m})$ & $8 \mathrm{H}$ \\
\hline $4.40(\mathrm{~m})$ & $9 \mathrm{H}$ \\
\hline $3.87(\mathrm{~s})$ & $3-\mathrm{OCH} 3$ \\
\hline $3.00(\mathrm{~s})$ & $\mathrm{N}-\mathrm{CH} 3$ \\
\hline
\end{tabular}

Structure investigation of complex $\left[\mathrm{Fe}\left(\mathrm{Cl}_{8} \mathrm{H}_{19} \mathrm{NO}_{3}\right)\right] \mathrm{Cl}_{2}$ by $\mathrm{FT}-\mathrm{IR}$, ${ }^{1} H$-NMR, $U V$-Visible, Raman and elemental analysis

The new codeine complex, $\left[\mathrm{Fe}\left(\mathrm{C}_{18} \mathrm{H}_{19} \mathrm{NO}_{3}\right)\right] \mathrm{Cl}_{2}$, has been synthesized and spectroscopically characterized. Complex formation of Fe (III) to codeine was also verified by ${ }^{1} \mathrm{H}-\mathrm{NMR}$, using DMSO - $\mathrm{d}_{6}$ as a solvent. The proton signals of the codeine shifted to lower field relative to the free alkaloid, because of the coordination with the $\mathrm{Fe}(\mathrm{III})$ ion that decreases the electron density of the codeine. Specially methoxy group in the position 6 of molecule $(\delta 3.87 \mathrm{ppm}$ before and $\delta 4.40 \mathrm{ppm}$ after coordination) is so decreased.

Table 4. ${ }^{1} \mathrm{H}-\mathrm{NMR}$ identification of codeine complex.

\begin{tabular}{|c|c|}
\hline Chemical shift $(\boldsymbol{\delta})$ & Assignment \\
\hline $6.82(\mathrm{~d})$ & $1 \mathrm{H}$ \\
\hline $7.01(\mathrm{~d})$ & $2 \mathrm{H}$ \\
\hline $5.81(\mathrm{~d})$ & $7 \mathrm{H}$ \\
\hline $5.96(\mathrm{~m})$ & $8 \mathrm{H}$ \\
\hline $4.72(\mathrm{~m})$ & $9 \mathrm{H}$ \\
\hline $4.40(\mathrm{~s})$ & $3-\mathrm{OCH} 3$ \\
\hline
\end{tabular}

The FT-IR spectrum of codeine complex as $\mathrm{KBr}$-disc was recorded in Table 5. The FT-IR spectrum band around $514 \mathrm{~cm}^{-1}$ and $581 \mathrm{~cm}^{-1}$ in iron complex are assigned to $[(\mathrm{Fe}-\mathrm{O})$ and $(\mathrm{Fe}-\mathrm{Cl})]$ vibrations respectively. The $\mathrm{C}=\mathrm{C}$ band of the free ligand is shifted by $40 \mathrm{~cm}^{-1}$ to lower frequencies in iron complex coordination through the carbon of vinyl group.

Table 5. Selected FT-IR data for codeine complex.

\begin{tabular}{|c|c|}
\hline $\boldsymbol{v}\left(\mathbf{~ c m}^{-1}\right)$ Experimental & Vibration \\
\hline 3412 & $\mathrm{OH}$ \\
\hline 1335 & $(\mathrm{CO})(\mathrm{O}-\mathrm{Me})$ \\
\hline 1123 & (Alken) $\mathrm{C}=\mathrm{C}$ \\
\hline 1453 & (Aromatic) $\mathrm{C}=\mathrm{C}$ \\
\hline 1275 & $\mathrm{C}-\mathrm{O}-\mathrm{C}$ \\
\hline 581 & $\mathrm{Fe}-\mathrm{O}$ \\
\hline 517 & $\mathrm{Fe}-\mathrm{Cl}$ \\
\hline
\end{tabular}

The electronic spectral data of the complex in acetonitrile are presented. There are two absorption peaks, in spectrum of ligand, which can be assigned to $\pi-\pi *$ and $\mathrm{n}-\pi *$ transitions. The electronic spectrum of complex shows a broad band at $370 \mathrm{~nm}$ attributable to the $\mathrm{B}_{2} \rightarrow \mathrm{B}_{1}$, and in $300 \mathrm{~nm}$ that belong to the $\mathrm{B}_{2} \rightarrow \mathrm{A}_{2}$, transition for $\mathrm{Fe}$ (III) ion.

\section{Anticancer activity}

The present study demonstrated that codeine dose-dependently reduced the viable cell number of two tumor cell lines MCF-7 and AGS. The objective of this study is to investigate the resulting anticancer properties on breast and stomach cancer cell lines. The cytotoxicity of Fe(III) complex on MCF-7 and AGS cell line were measured using a slightly modified MTT assay at 72 hours [11]. As a reference, the cytotoxic activity of codeine was tested at 72 hours and an IC50 value was obtained.

The results showed that the viability of AGS cells was clearly inhibited in a time and dose dependent manner. TAKEUCHI and et al showed that codeinone dose - dependently reduced the viable cell number of HSC-2 cells $(0 \sim 20 \mu \mathrm{M})$.

The cytotoxic activity of codeinone was dose-dependently inhibited by $\mathrm{N}$-acetyl-L-cysteine [30]. MTT assay indicated that different concentrations of the complex reduced the inhibition of AGS cells after 24, 48 and $72 \mathrm{~h}$ of 
incubation with IC50 value of 10, 2.5 and $1.56 \mathrm{mmol}$, and the inhibition of MCF-7 cells after $72 \mathrm{~h}$ of incubation with IC50 value of $2.5 \mathrm{mmol}$, respectively.

The inhibitory concentration of $80 \%$ (IC 80 ) of (codeine $+\mathrm{Fe}$ ) on AGS was $100 \mathrm{mmol}$, and (codeine $+\mathrm{Fe}$ ) on MCF-7 was $100 \mathrm{mmol}$. The results showed that the viability of AGS, MCF- 7 cells was clearly inhibited in a time and dose dependent manner in Figure 2. The current study demonstrates that codeine complex, induces apoptosis in AGS and MCF-7 cell lines.

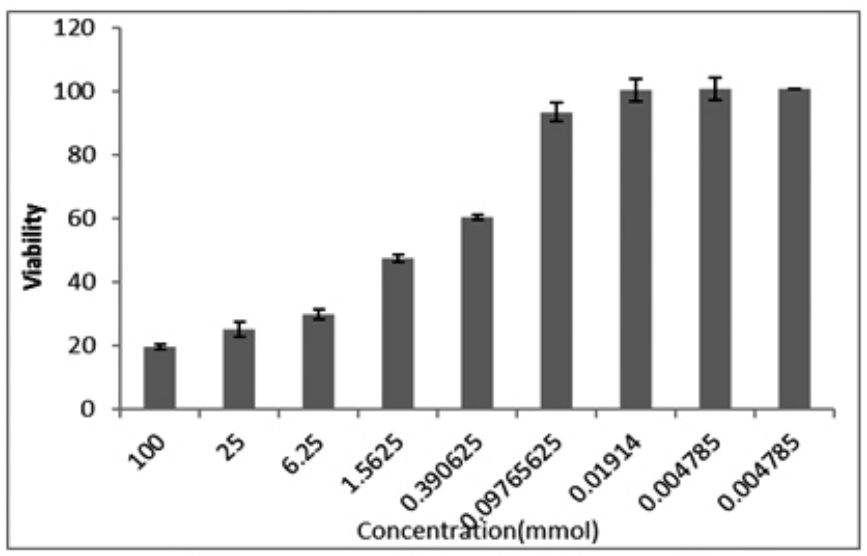

AGS concentration (100 mmol)

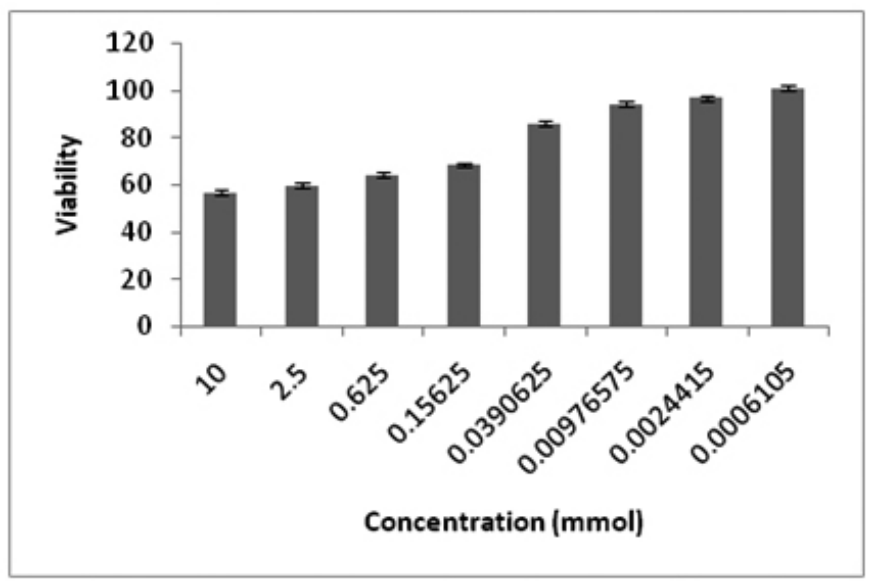

AGS concentration (10 mmol)

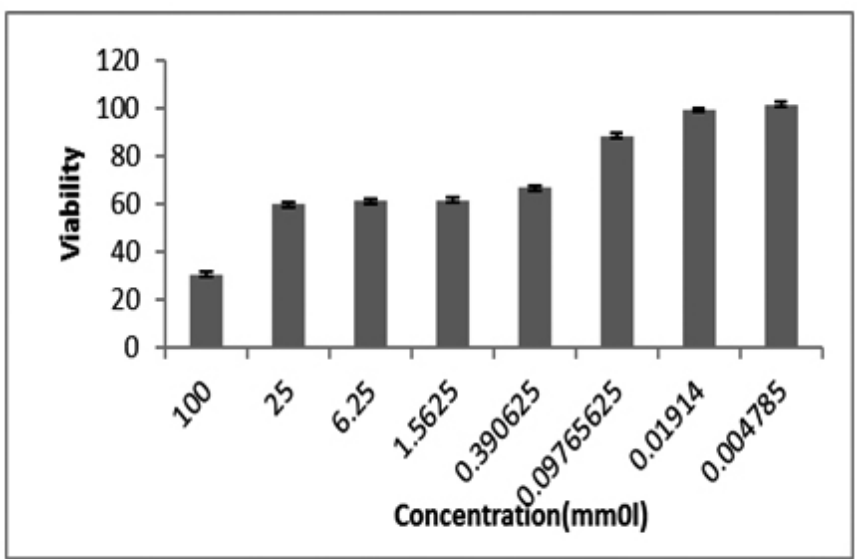

MCF-7 concentration (100 mmol)

Figure 2. The effects of codeine complex on AGS and MCF-7 cell lines that were measured using MTT cell viability assay.
Cell proliferation was significantly reduced at $10 \mu \mathrm{M}$ morphine in MCF-7 cells. The combination of codeine $(250 \mu \mathrm{M})$ and $\mathrm{Nx}(250 \mu \mathrm{M})$ was as effective as either agent alone in MDA-MB231 cells and was more potent than either agent alone in MCF-7 and HT-29 cells [31]. This suggest that the apoptosis induction by codeine complex is coupled with the changes in the activity of these cells.

Based on the results of this study, codeine complex has more anticancer effect on AGS and MCF-7cells. Therefore, codeine complex should be good naturally drug for cancer preventions. In the present study, the growth inhibitory effects of codeine were increased by $\mathrm{Fe}(\mathrm{III})$, suggesting that the combination of morphine and Nx might be useful to supplement cancer therapy. We have recently found that codeinone had high cytotoxic activity against various cancer cell lines [28, 29], as compared with codeine, suggesting its applicability for the treatment of cancer.

\section{In-vitro anti-bacterial activity}

The mean diameters of microbial growth inhibited by different complexes are shown in Table 2. Inhibition zones larger than $5 \mathrm{~mm}$ indicated antimicrobial activity. No antibacterial activity of Ligand and synthetic complex as observed against Staphylococcus aureus, Pseudomonas aeruginosa and Streptococcus pyogenes, whereas ligand showed strong antibacterial activity against Escherichia coli $(10 \mathrm{~mm})$, one of the most common Gram-negative bacteria. This strong antibacterial effect could be due to flavonoids.

The data obtained by the disk diffusion method showed that only $\mathrm{C}_{18} \mathrm{H}_{20} \mathrm{NO}_{3} \cdot \mathrm{PO}_{4}$ had antibacterial activity. Among the bacteria, Escherichia coli was sensitive bacteria for ligand .On the other hand, the codeine complex had no activity against Escherichia coli, the Gram-negative bacteria. This could be related to the outer membrane acting as a permeability barrier in these bacteria [10]. The antimicrobial activity of complexes demonstrated in this study can be added to the already known beneficial biological properties of these compounds to the human health.

\section{CONCLUSION}

The new codeine complex, $\left[\mathrm{Fe}\left(\mathrm{C}_{10} \mathrm{H}_{10} \mathrm{NO}_{3}\right)\right] \mathrm{Cl}_{2}$, has been synthesized and spectroscopically characterized. Complexation of $\mathrm{Fe}$ (III) to codeine was also verified by ${ }^{1} \mathrm{H}-\mathrm{NMR}$, using DMSO - $\mathrm{d}_{6}$ as a solvent.

The proton signals of the codeine shifted to lower field relative to the free alkaloid, because of the coordination with the Fe(III) ion that decreases the electron density of the codeine. Specially methoxy group in the position 6 of molecule $(\delta 3.87 \mathrm{ppm}$ before and $\delta 4.40 \mathrm{ppm}$ after coordination) is so decreased.

The FT-IR spectrum band around $514 \mathrm{~cm}^{-1}$ and $581 \mathrm{~cm}^{-1}$ in iron complex are assigned to $[(\mathrm{Fe}-\mathrm{O})$ and $(\mathrm{Fe}-\mathrm{Cl})]$ vibrations respectively. The $\mathrm{C}=\mathrm{C}$ band of the free ligand is shifted by $40 \mathrm{~cm}^{-1}$ to lower frequencies in iron complex coordination through the carbon of vinyl group.

The electronic spectral data of the complex in acetonitrile are presented. There are two absorption peaks, in spectrum of ligand, which can be assigned to $\pi-\pi *$ and $n-\pi *$ transitions. The electronic spectrum of complex shows a broad bandat $370 \mathrm{~nm}$ attributable to the $\mathrm{B}_{2} \rightarrow \mathrm{B}_{1}$, and in $300 \mathrm{~nm}$ that belong to the $\mathrm{B}_{2} \rightarrow \mathrm{A}_{2}$, transition for $\mathrm{Fe}(\mathrm{III})$ ion.

The microorganisms tested were Pseudomonas aeruginosa, Staphylococcus aureus, Streptococcus pyogenes and Escherichia coli, from clinical isolates. Maximum 6 discs were applied on each plate and they were incubated at 37 ${ }^{\circ} \mathrm{C}$ for 24 hours. Zone of inhibition was measured including the disc diameter $(6 \mathrm{~mm})$.

\section{ACKNOWLEDGMENTS}

We gratefully acknowledge the financial support from the Research Council of Imam Khomeini International University.

\section{REFERENCES}

1. A.A. Adedapo, F.O. Jimoh. BMC Complement Altern Med. 9, 21-28 (2009).

2. S.A. Adesegun, A. Fajana, C.I. Orabueze, H.A.B. Coker. Evid Based Complement Altern Med. 6, 227-231 (2009).

3. L.E. Alcaraz, S.E. Blanco, O.N. Puig, F. Tomas. J TheorBiol. 205, 231-240 (2000).

4. A.W. Bauer, W.M.M. Kirby, J.C. Sherris, M. Turck. J. Clin. Pathol. 45, 493-96 (1966).

5. M.J. Balunas, A.D. Kinghorn. Life Sciences. 78, 431-441 (2005).

6. G.M. Cragg, D.J. Newman, K.M. Snader. J Nat Prod. 60, 52-60 (1997). 
7. H.C. Chang, G.H. Huang, D.C. Agrawal, C.L. Kuo. Bot Studies. 48, 397406 (2007).

8. H. Grunicke, W. Doppler, W. Helliger. Arch Geschwulstforsch. 56, 193201 (1986).

9. T.P.T. Cushnie, A.J. Lamb. Int J Antimicrob Agents. 26, 343-356 (2005).

10. N.R. Farnsworth, O. Akerele, A.S. Bingel, D.D. Soejarto. Bull World Health Organ. 63, 965-981 (1985).

11. G.J. Kaur, D.S. Arora. BMC Complement Altern Med. 9, 30-38 (2009).

12. Y.R. Lin, W. Shi, X. Shen, H.M. Curr Cancer Drug Targets. 8, 634-46 (2008).

13. R.A. Mothana, U. Lindequist, R. Gruenert, P.J. Bednarski. BMC Complement Altern Med. 9, 712-719 (2008).

14. A.D. Corbett, G. Henderson, A. McKnight, S.J. Paterson. Britannia Journal Pharmacology. 147(suppl. 1), S153-S162 (2006).

15. C. Boettcher, M. Fellermeier, C. Boettcher, B. Drager, M.H. Zenk. Proceedings of the National Academy of Science, PNAS. 102(24), 8495$8500(2005)$.

16. C. Poeaknapo, J. Schmidt, M. Brandsch, B. Drager, M.H. Zenk. Proceedings of the National Academy of Science. 101(39), 14091-14096 (2004).

17. W. Zhu, Y. Ma, P. Cadet, D. Yu, T.V. Bilfinger, E. Bianchi, G.B. Stefano. Molecular Brain Research. 117(1), 83-90 (2003).

18. M.R. Zarrindast, A. Lahmi, S. Ahamadi. Journal of Psychopharmacology. 22(8), 865-871 (2008)

19. D.P. Van Kammen, J.P. Docherty, S.R. Marder, J.E. Rosenblatt, W.E.Jr. Bunney. Psychopharmacology (Berlin). 87, 111-115 (1985).

20. E. Gottberg, L. Grondin, T.A. Reader. Journal of Neurosis Research. 22, 338-345 (1989).
21. A.R. Dehpour, H. Farsam, M. Azizabadi-Farahani. Neuropharmacology. 34, 115-121 (1995)

22. A. Alborzi, S.E. Mehr, F. Rezania, S. Badakhshan, T. Mombeini, H. Shafaroodi, L. Moezi. European Journal of Pharmacology. 545, 123-128 (2006).

23. I.N. Johnston, R.F. Westbrook. Behavior Brain Research. 151, 151-158 (2004).

24. M. Lopez-Grancha, P. Flores, J. Glowa, A.L. Riley. Pharmacologic Biochemical Behavior. 80, 195-202 (2005).

25. A.S. Kuwar, S.R. Shimpi, P.P. Mahulikar, R.S. Bendre. Journal of Scientific \& Industrial Research. 65, 665-669 (2006)

26. Y. Yu-Ye, X. Hui-Duo, L. Jian-Feng, Z. Guo-Liang. Molecules. 14, 17471754 (2009).

27. M.A. Zayed, M.F. Hawash, M.A. Fahmey. Spectrochem. Acta. 363-371 (2006).

28. M.A. Zayed, M.S. El-Morsy. J. Chem. 23, 1-11 (1980).

28. I. Hatsukari, N. Hitosugi, I. Matsumoto, H. Nagasaka, H. Sakagami. Anticancer Res. 23, 2413-2418 (2003).

29. N. Hitosugi, I. Hatsukari, R. Ohno, K. Hashimoto, S. Mihara, S. Mizukami, S. Nakamura, H. Sakagami, H. Nagasaka, I. Matsumoto, M. Kawase. Anesthesiology. 98, 643-650 (2003).

30. R. Takeuchi, H. Hoshijima, N. Onuki, H. Nagasaka, S. Chowdhury, M. Kawase, H. Sakagami. Anticancer Research. 25, 4037-4042 (2005).

31. I. Tegeder, S. Gro"sch, A. Schmidtko, A. Ha"ussler, H. Schmidt, E. Niederberger, K. Scholich, G. Geisslinger. Cancer research. 1846-1852 (2003)63. 